\title{
RESPONS SISWA SMK TERHADAP E-TRAINING PERSIAPAN SELEKSI MASUK PERGURUAN TINGGI BERBASIS ANDROID
}

\author{
Rini Widyastuti ${ }^{1}$, Karmila Suryani ${ }^{2}$, Rona Taula Sari ${ }^{3}$, \\ Chairumah Hasri $^{4}$, Fauziah ${ }^{5}$ \\ ${ }^{1,2,4}$ Pendidikan Teknik Informatika dan Komputer, Universitas Bung Hatta \\ Jalan Bagindo Azizchan, Aia Pacah, Padang, Sumatra Barat \\ ${ }^{3}$ Pendidikan Biologi, Universitas Bung Hatta \\ Jalan Bagindo Azizchan, Aia Pacah, Padang, Sumatra Barat \\ ${ }^{5}$ Pendidikan Matematika, Universitas Bung Hatta \\ Jalan Bagindo Azizchan, Aia Pacah, Padang, Sumatra Barat \\ 1e-mail: riniwidyastuti@bunghatta.ac.id
}

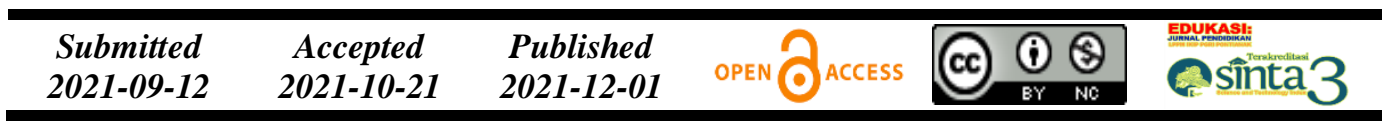

\begin{abstract}
Abstrak
Penelitian bertujuan untuk menghasilkan aplikasi E-Training berbasis Android yang valid dan praktis untuk seleksi masuk perguruan tinggi. Penelitian menggunakan model pengembangan four- $D$ dengan 4 tahapan, yaitu define, design, develop, dan dessiminate. Alat pengumpul data menggunakan lembar validasi dan angket. Teknik analisis data melalui uji validitas produk dengan melibatkan pakar/ahli, yaitu ahli desain dan ahli materi, serta uji praktikalitas yang melibatkan 28 siswa SMK Negeri 2 Pariaman. Hasil penelitian menunjukkan bahwa aplikasi E-Training berbasis Android dinyatakan sangat valid berdasarkan aspek substansi materi, komunikasi visual, desain evaluasi, dan pemanfaatan software, serta respons siswa terhadap aplikasi menunjukkan hasil dengan kriteria sangat praktis ditinjau dari daya tarik, proses penggunaan, kemudahan penggunaan, dan alokasi waktu. Berdasarkan hasil penelitian, maka dapat disimpulkan bahwa aplikasi E-Training dapat digunakan bagi siswa sebagai latihan untuk persiapan seleksi masuk perguruan tinggi.
\end{abstract}

Kata Kunci: Android; aplikasi E-Training; seleksi masuk perguruan tinggi.

\begin{abstract}
The research aimed to produce valid and practical Android-based E-Training for college entrance selection. This research used a four-D development model with 4 stages, namely define, design, develop, and desiminate. The data collection tool used validation sheets and questionnaires. The data analysis technique was through product validity testing involving experts, namely design experts and material experts, as well as practicality tests involving 28 students of SMK N 2 Pariaman. The results showed that Android-based E-Training was declared to be very valid based on aspects of material substance, visual communication, evaluation design, and software utilization, and student responses to the application showed results with very practical criteria in terms of attractiveness, process of use, ease of use, and time allocation. Based on the research results, it can be concluded that ETraining can be used for students as an exercise to prepare for college entrance selection.
\end{abstract}

Keywords: Android; E-Training application; college entrance selection. 


\section{PENDAHULUAN}

Proses pembelajaran yang diamanatkan pada Peraturan Pemerintah Nomor 32 Tahun 2013 yaitu peserta didik diberikan kesempatan untuk mengembangkan potensi dan kreativitasnya sehingga diharapkan memiliki keterampilan sesuai keahliannya. Realitanya, lulusan sekolah menengah kejuruan (SMK) merupakan penyumbang pengangguran intelektual terbesar setiap tahunnya. Hal tersebut dipertegas berdasarkan data yang dimiliki Badan Pusat Statistik (BPS) tahun 2021 tentang Tingkat Pengangguran Terbuka (TPT) yang didominasi dari lulusan SMK sebesar 6,61\%. Pemerintah menganjurkan agar lulusan SMK dapat mengikuti seleksi masuk perguruan tinggi sehingga mengurangi tingkat pengganguran. Banyak faktor yang sangat memengaruhi jumlah pengangguran lulusan SMK tersebut, salah satunya yaitu indeks pembangunan manusia melalui siswa SMK yang masih banyak belum lolos masuk perguruan tinggi (Putri et al., 2021).

Pemerintah mengeluarkan Instruksi Presiden Nomor 9 Tahun 2016 tentang Peningkatan Kualitas dan Daya Saing Lulusan Vokasi terkait dengan mempersiapkan lulusan kejuruan (vokasi) yang berkualitas melalui kegiatan pelatihan sebelum mengikuti seleksi. Lembaga pendidikan formal maupun nonformal pada masa pandemi COVID-19 hanya menerapkan pembelajaran secara online. Pemilihan metode pembelajaran dan pelatihan secara online dapat membantu siswa dalam memahami pembelajaran (Jumrawarsi \& Suhaili, 2021). Pelatihan yang sudah ada masih kurang efektif dan tidak optimal karena materi yang digunakan masih kurang bervariasi, monoton, serta terbatas, sehingga masih belum sesuai dengan kebutuhan siswa SMK (Vann et al., 2021). Berdasarkan uraian tersebut, maka dibutuhkan solusi mendesak dan tepat sasaran. Alternatif solusi yang dapat dilakukan yaitu melalui program pendidikan dan pelatihan (diklat) seperti pengembangan aplikasi E-Training berbasis Android dalam persiapan seleksi masuk perguruan tinggi untuk siswa SMK.

Sebuah aplikasi E-Training berbasis Android dan online dapat memberi pengalaman belajar pada siswa secara utuh (Syahmaidi, 2017). Penggunaan 
aplikasi E-Training dapat meningkatkan pengetahuan, kepercayaan diri, dan kompetensi dengan biaya rendah dan dengan akses mudah (Schulte \& Grantz, 2014). Aplikasi E-Training menjadi salah satu pilihan bagi siswa untuk mendapatkan pelayanan dan informasi dalam menunjang pengetahuan secara mandiri (Lesmana et al., 2021). Praktik pelatihan yang masih konvensional tidak mampu menyediakan pelatihan yang dibutuhkan karyawan secara efektif karena keterbatasan dana, jumlah pelatih, waktu, dan fasilitas ruang kelas (Harris et al., 2020). Berdasarkan uraian tersebut, maka pelatihan berbasis komputer cocok untuk mengatasi permasalahan yang dihadapi.

Pelatihan Berbasis Komputer (PBK) atau Computer Based Training (CBT) merupakan media komunikasi berbasis CD/LAN/WEB/Android interactive yang dibuat sebagai alat pelatihan dan pengenalan materi internal suatu lembaga atau institusi. Siswa dapat belajar melalui sebuah pelatihan menggunakan komputer pada pelaksanaan pembelajaran secara CBT. CBT sangat bermanfaat dalam melatih siswa untuk menggunakan aplikasi di komputer karena CBT dapat diintegrasikan dengan berbagai aplikasi lainnya (Panyahuti et al., 2019). Berdasarkan fenomena dan permasalahan yang telah diuraikan, maka penelitian bertujuan untuk menghasilkan sebuah aplikasi ETraining berbasis Android untuk membantu siswa masuk perguruan tinggi.

\section{METODE}

Jenis penelitian yang digunakan adalah penelitian dan pengembangan dengan desain penelitian menggunakan four-D-models yang terdiri dari pendefinisian (define), perancangan (design), pengembangan (develop), dan penyebaran (disseminate). Langkah-langkah pengembangan terlihat di Gambar 1 . Gambar 1 menjelaskan bahwa tahap pertama yaitu pendefinisian. Pendefinisian yang dilakukan yaitu menganalisis karakteristik siswa, konsep terhadap mata pelajaran yang ditambahkan pada aplikasi, dan file yang dibutuhkan dalam perancangan sistem, seperti aktor yang terlibat. Tahap kedua adalah perancangan. Perancangan yang dilakukan yaitu membuat prototype menggunakan Unified Modeling Language (UML) melalui identifikasi aktor, use case, dan use case 
Edukasi: Jurnal Pendidikan, Volume 19 Nomor 2 Tahun 2021

Respons Siswa SMK terhadap E-Training Persiapan Seleksi Masuk.......

Rini Widyastuti, Karmila Suryani, Rona Taula Sari,

Chairumah Hasri, Fauziah

Halaman 230-244

diagram. Tahap ketiga adalah pengembangan. Pengembangan yang dilakukan yaitu validasi produk oleh 1 ahli media dan 1 ahli materi, serta uji coba aplikasi ETraining kepada siswa. Sedangkan tahap penyebaran secara meluas dilakukan dengan cara mempublikasikan hasil penelitian melalui artikel ilmiah.
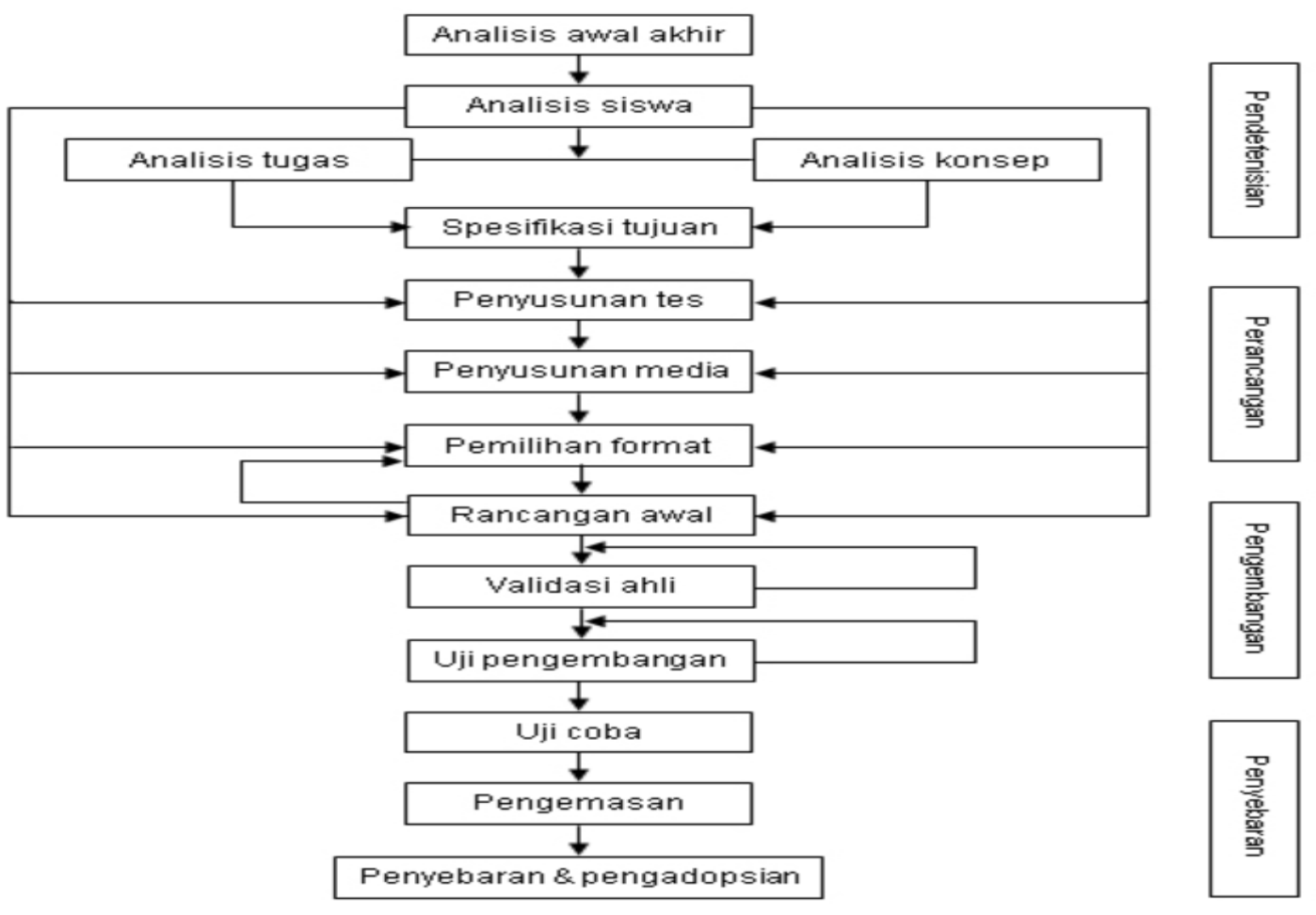

\section{Gambar 1 Tahapan Penelitian Four-D}

Subjek penelitian adalah siswa SMK Negeri 2 Kota Pariaman berjumlah 28 siswa. Alat pengumpul data menggunakan lembar validasi dan angket praktikalitas. Kisi-kisi lembar validasi terlihat pada Tabel 1 dan angket praktikalitas terlihat pada Tabel 2 .

\section{Tabel 1 Kisi-Kisi Lembar Validasi}

\section{Kisi-Kisi}

Indikator

Substansi materi Kebenaran; cakupan materi; kekinian; keterbacaan.

Komunikasi Navigasi; huruf; media (suara, gambar, animasi); warna; visual animasi (slide); layout.

Desain evaluasi Judul; mata pelajaran; capaian pembelajaran; materi; soal training; latihan/tes/simulasi; penyusun; referensi.

Pemanfaatan Interaktivitas (umpan balik dari sistem ke pengguna); software software pendukung; originalitas. 
Tabel 2 Kisi-Kisi Angket Praktikalitas

\begin{tabular}{ll}
\hline \multicolumn{1}{c}{ Kisi-Kisi } & \multicolumn{1}{c}{ Indikator } \\
\hline $\begin{array}{l}\text { Daya tarik } \\
\text { Proses penggunaan }\end{array}$ & $\begin{array}{l}\text { Tampilan; penggunaan gambar dan warna. } \\
\text { Tidak membosankan; menjawab soal dengan cepat; } \\
\text { menggunakan bahasa baku. }\end{array}$ \\
Kemudahan & Aplikasi mudah digunakan; soal-soal mudah dijawab; \\
penggunaan & materi mudah diulang. \\
Waktu & Menggunakan alokasi waktu. \\
\hline
\end{tabular}

Teknik analisis data yang digunakan yaitu pengujian terhadap kevalidan dan kepraktisan aplikasi. Analisis validasi berupa substansi materi, tampilan komunikasi visual, desain, dan pemanfaatan software. Berdasarkan instrumen validasi yang dibuat, maka dilakukan beberapa langkah, yaitu: (1) Memberikan skor dengan jawaban kriteria berdasarkan skala Likert yang terlihat pada Tabel 3; (2) Menentukan skor tertinggi dengan cara melakukan perkalian terhadap jumlah validator dan jumlah maksimum; (3) Menentukan skor yang diperoleh dari masing-masing validator dengan cara menjumlahkan semua skor yang diperoleh dari masing-masing indikator; (4) Menentukan nilai validitas dengan cara membagi jumlah skor yang diperoleh dengan jumlah skor tertinggi yang kemudian dikalikan 100\%; dan (5) Memberikan penilaian validitas. Kriteria penilaian validasi isi (Purwanto, 2016) terlihat pada Tabel 4.

Tabel 3 Kriteria Skala Likert

\begin{tabular}{cc}
\hline Kriteria & Skor \\
\hline Sangat Tidak Setuju (STS) & 1 \\
Tidak Setuju (TS) & 2 \\
Cukup Setuju (CS) & 3 \\
Setuju (S) & 4 \\
Sangat Setuju (SS) & 5 \\
\hline
\end{tabular}

Tabel 4 Kriteria Nilai Uji Validasi

\begin{tabular}{cc}
\hline Nilai (\%) & Kategori \\
\hline $90-100$ & Sangat valid \\
$80-89$ & Valid \\
$65-79$ & Cukup valid \\
$55-64$ & Kurang valid \\
$\leq 54$ & Sangat tidak valid \\
\hline
\end{tabular}


Analisis praktikalitas menggunakan angket digunakan untuk melihat manfaat penggunaan aplikasi E-Training berbasis Android dengan analisis persentase (Purwanto, 2016) menggunakan rumus (1).

$$
\text { Nilai praktikalitas }=\frac{\text { jumlah skor yang diperoleh }}{\text { jumlah skor tertinggi }} \times 100 \%
$$

Kriteria penilaian kepraktisan (Purwanto, 2016) terlihat di Tabel 5.

Tabel 5 Kriteria Uji Praktikalitas

\begin{tabular}{cc}
\hline Nilai (\%) & Kategori \\
\hline $86-100$ & Sangat Praktis \\
$76-85$ & Praktis \\
$60-75$ & Cukup Praktis \\
$55-59$ & Kurang Praktis \\
$\leq 54$ & Sangat tidak Praktis \\
\hline
\end{tabular}

\section{HASIL DAN PEMBAHASAN}

Berdasarkan analisis kebutuhan (tahap pendefinisian) diperoleh hasil bahwa 98\% siswa menggunakan Android untuk mencari informasi tambahan dan belajar daring. Para siswa menyukai warna biru, hal tersebut dibutuhkan dalam pemilihan backgroud dari aplikasi. Pemilihan warna biru untuk background dapat merangsang kemampuan berkomunikasi, ekspresi artistik, dan juga sebagai simbol kekuatan (Essays, 2015). Analisis konsep diperoleh melalui soal-soal yang dimuat dalam aplikasi E-Training berbasis Android untuk seluruh mata pelajaran yang berhubungan dengan ujian masuk perguruan tinggi, seperti Bahasa Indonesia, Matematika, Ilmu Pengerahuan Alam, Ilmu Pengetahuan Sosial, Bahasa Inggris, dan mata pelajaran kejuruan. Hasil perancangan aplikasi ETraining untuk tampilan awal terlihat seperti Gambar 2. Gambar 2 memperlihatkan nama aplikasi yang telah dirancang dengan latar belakang yang didominasi dengan warna biru. Pemilihan warna untuk halaman awal aplikasi berdasarkan hasil analisis kebutuhan siswa, bahwa siswa lebih menyukai warna biru. Hal tersebut sesuai dengan harapan penggunaan aplikasi yang dapat menumbuhkan komunikasi yang baik antara user dan aplikasi, sehingga siswa sebagai user dapat lebih nyaman untuk melakukan latihan. Halaman utama aplikasi E-Training terlihat seperti Gambar 3. 


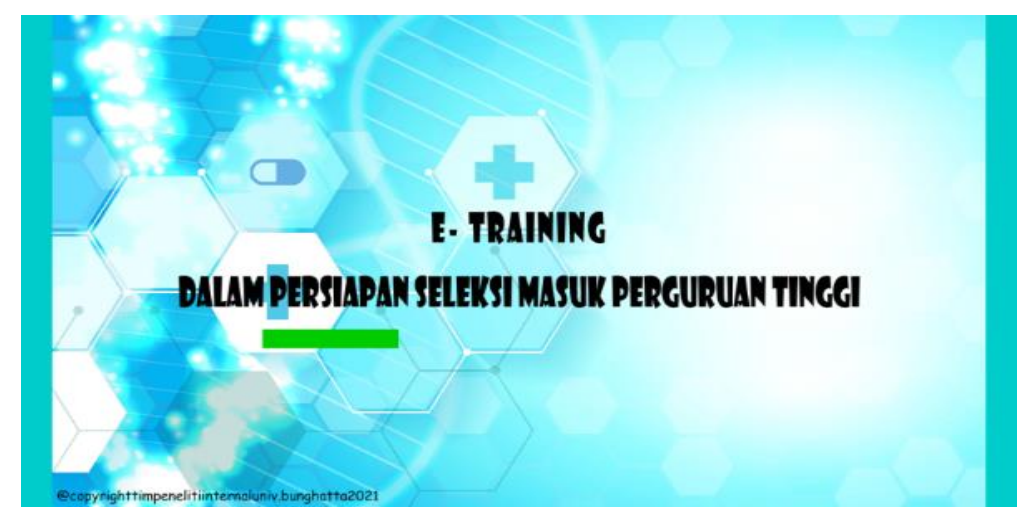

Gambar 2 Halaman Intro

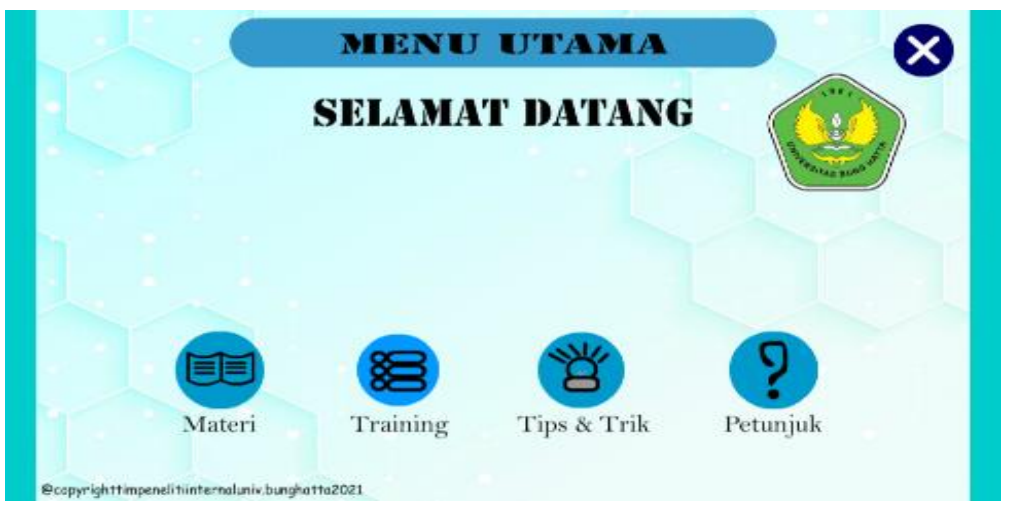

Gambar 3 Halaman Home

Gambar 3 memperlihatkan semua komponen yang terdapat pada aplikasi ETraining. Terlebih dahulu siswa diarahkan untuk melihat menu petunjuk penggunaan aplikasi E-Training. Petunjuk tersebut mempermudah siswa dalam menggunakan aplikasi sehingga siswa benar-benar melaksanakan latihan untuk menghadapi ujian masuk perguruan tinggi. Apabila siswa membutuhkan pengayaan pengetahuan tentang pelajaran di sekolah, maka siswa dapat memilih submenu materi. Materi yang disiapkan sesuai dengan mata pelajaran yang berhubungan dengan ujian masuk perguruan tinggi.

Aplikasi E-Training dilengkapi dengan submenu tips dan trik yang dapat membantu siswa dalam menjawab soal-soal untuk masuk perguruan tinggi. Tips dan trik tersebut sangat bermanfaat karena ketika siswa menjawab soal-soal ujian tidak mempunyai pola sehingga terdapat siswa yang tidak lolos saat ujian masuk perguruan tinggi. Siswa juga dapat melalukan pelatihan secara mandiri melalui submenu training seperti Gambar 4. 


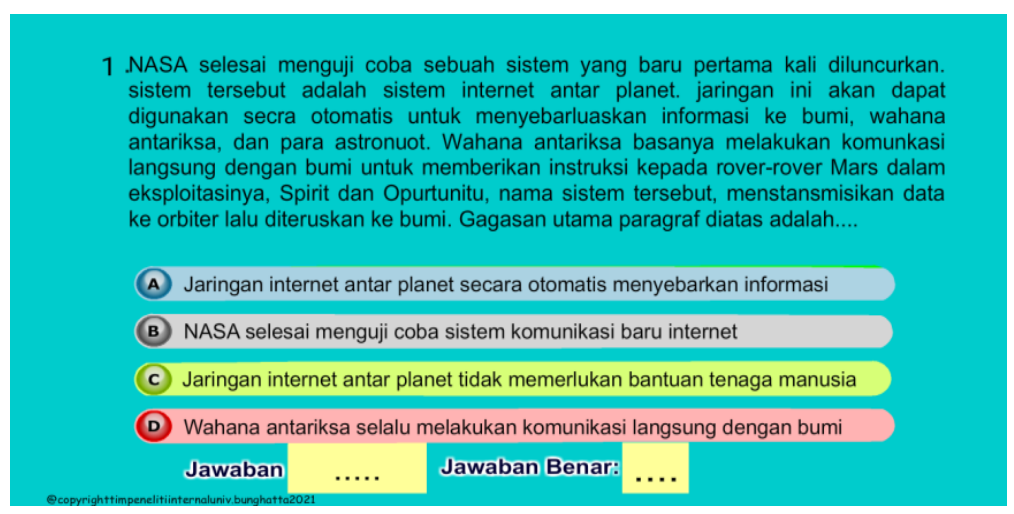

\section{Gambar 4 Submenu Training}

Gambar 4 menjelaskan submenu training yang berisi soal-soal ujian masuk perguruan tinggi yang berbasis higher order thinking skills (HOTS). Soal-soal tersebut berbentuk objektif. Setelah siswa menjawab soal, maka langsung diketahui apakah soal yang dijawab siswa benar atau salah. Aplikasi E-Training berbasis Android terdiri dari 120 soal yang dibagi menjadi 3 bagian, masingmasing bagian terdiri dari 40 soal dengan waktu yang sudah ditentukan. Aplikasi dapat digunakan siswa untuk melakukan latihan ujian masuk perguruan tinggi. Setelah siswa berhasil menjawab semua soal yang ada dalam aplikasi E-Training, maka secara otomatis penilaian diproses langsung oleh sistem berdasarkan aturan penskoran ujian masuk perguruan tinggi. Siswa dapat mengukur kemampuannya untuk masuk perguruan tinggi setelah menggunakan aplikasi E-Training berbasis Android. Apabila siswa belum lulus, maka siswa dapat mengulang pelajaran melalui submenu materi.

Selanjutnya aplikasi E-Training yang sudah dihasilkan uji kevalidan dan uji coba skala kecil untuk mengukur kepraktisannya. Hal tersebut merupakan representasi dari tahap develop. Hasil kevalidan aplikasi E-Training dapat dilihat di Tabel 9. Berdasarkan Tabel 9, terlihat bahwa aplikasi E-Training yang dikembangkan dinyatakan sangat valid oleh validator sehingga aplikasi ETraining dapat dilakukan uji coba untuk melihat kepraktisannya. Hal tersebut sesuai dengan hasil penelitian terdahulu yang menjelaskan bahwa aplikasi ETraining yang telah dinyatakan valid sudah dapat dilakukan uji coba secara meluas kepada siswa (Dhir et al., 2021). 
Tabel 9 Nilai Validasi Pakar

\begin{tabular}{|c|c|c|c|c|c|}
\hline \multirow{2}{*}{ Aspek Penilaian } & \multicolumn{2}{|c|}{ Validator } & \multirow{2}{*}{ Jumlah } & \multirow{2}{*}{$\begin{array}{l}\text { Nilai } \\
\text { Kevalidan }\end{array}$} & \multirow{2}{*}{ Kriteria } \\
\hline & 1 & 2 & & & \\
\hline Subtansi materi & 10 & 12 & 22 & $84,61 \%$ & Valid \\
\hline $\begin{array}{l}\text { Tampilan komunikasi } \\
\text { visual }\end{array}$ & 19 & 19 & 38 & $100 \%$ & Sangat valid \\
\hline Desain E-Training & 25 & 27 & 52 & $96,29 \%$ & Sangat valid \\
\hline Pemanfaatan software & 9 & 9 & 18 & $81,81 \%$ & Valid \\
\hline Rata-Rata & & & 98 & $92,44 \%$ & Sangat valid \\
\hline
\end{tabular}

Berdasarkan substansi materi, terlihat bahwa kedua validator mempunyai penilaian yang sama terhadap materi pada subindikator kekinian dan keterbacaan. Sementara untuk subindikator kebenaran dan cakupan, materi penilaiannya berbeda. Secara keseluruhan, penilaian validator terhadap substansi materi berada pada kategori valid sehingga aplikasi E-Training dapat membantu siswa dalam menghadapi seleksi masuk perguruan tinggi. Hal tersebut sesuai dengan hasil penelitian terdahulu bahwa sebuah aplikasi/media pembelajaran dapat membantu siswa dalam memahami sebuah materi jika substansi materi sudah dinyatakan valid (Annas et al., 2021; Puniyanti \& Rahayu, 2021; Arpan \& Sadikin, 2020).

Subindikator tampilan komunikasi visual dan desain aplikasi E-Training, kedua validator memberi penilaian yang sama yaitu berada pada kategori sangat valid sehingga aplikasi E-Training dapat digunakan dengan mudah oleh siswa. Sebuah aplikasi berbasis online akan mudah digunakan apabila tampilan komunikasi visualnya baik dan desainnya menarik (Sila \& Kamaludin, 2021). Jika dilihat dari indikator penggunaan software aplikasi E-Training menggunakan lebih dari 3 software sehingga kedua validator memberikan penilaian yang berada pada kategori valid. Aplikasi E-Training yang dibangun menggunakan lebih dari 3 software sehingga memberikan hasil lebih baik dan lengkap (Lesmana et al., 2021). Berdasarkan penilaian validator terhadap aplikasi E-Training, maka dilakukan uji praktikalitas. Perolehan nilai praktikalitas berdasarkan angket yang telah disebarkan terlihat di Tabel 10. 
Tabel 10 Nilai Praktikalitas

\begin{tabular}{lcc}
\hline \multicolumn{1}{c}{ Aspek Penilaian } & Nilai Kepraktisan & Kriteria \\
\hline Daya tarik & 91,43 & Sangat Praktis \\
Proses penggunaan & 90,48 & Sangat Praktis \\
Kemudahan & 85,57 & Praktis \\
penggunaan & & \\
Alokasi waktu & 80,72 & Praktis \\
\hline Rata-Rata & $\mathbf{8 7 , 0 5}$ & Sangat Praktis \\
\hline
\end{tabular}

Tabel 10 memperlihatkan pendapat siswa mengenai aplikasi E-Training yang telah dikembangkan. Hasil yang diperoleh bahwa aplikasi E-Training dapat menarik perhatian dan membuat siswa semangat untuk melakukan pelatihan dalam mempersiapkan diri untuk masuk perguruan tinggi. Hal tersebut terlihat dari penilaian terhadap daya tarik dan proses penggunaan berada pada kategori sangat praktis. Sementara alokasi waktu yang disediakan dalam aplikasi ETraining membuat siswa lebih tertantang untuk mengatur strategi bagaimana agar bisa meyelesaikan jawaban ujian lebih cepat. Apabila siswa dapat mengerjakan soal latihan sesuai alokasi waktu yang disediakan, maka siswa merasa tertarik untuk menggunakannya (Lesmana et al., 2021). Pendapat siswa mengenai aplikasi E-Training secara detail terlihat pada Gambar 5.

\section{Sebaran Indikator Daya Tarik}

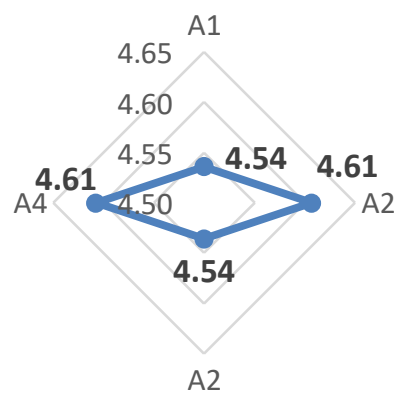

\section{Gambar 5 Sebaran Indikator Daya Tarik}

Gambar 5 menjelaskan bahwa sebaran perolehan nilai untuk indikator daya tarik terhadap aplikasi E-Training berada diatas angka 3 skala Likert. Hal terebut menunjukkan bahwa siswa sangat tertarik menggunakan aplikasi E-Training untuk mempersiapkan diri dalam menghadapi ujian masuk perguruan tinggi. Hal 
tersebut sesuai dengan hasil penelitian terdahulu bahwa penggunaan aplikasi ETraining bagi calon pemimpin di sekolah sangat menarik karena desainnya yang bagus, sehingga saat melaksanakan latihan peserta dapat merasakan kenyamanan dan menyenangkan (Hassan et al., 2020). Penilaian terhadap proses penggunaan terlihat pada Gambar 6.

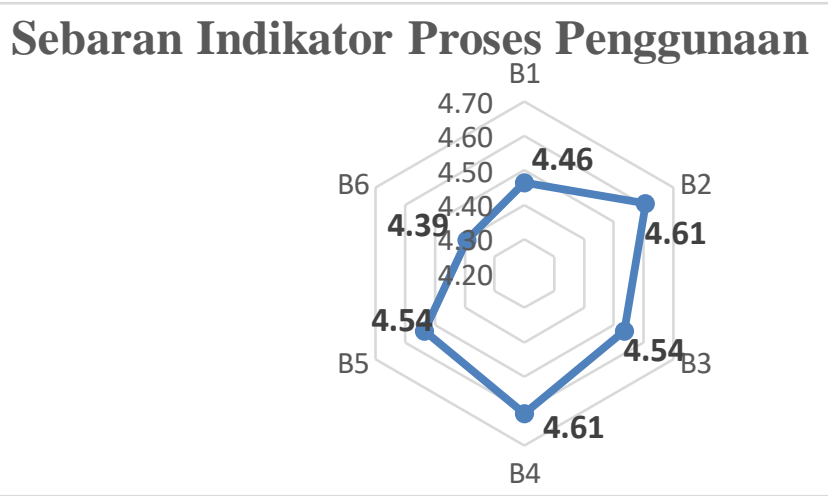

\section{Gambar 6 Sebaran Indikator Proses Penggunaan Aplikasi E-Training}

Gambar 6 merupakan sebaran penilaian terhadap indikator proses penggunaan aplikasi E-Training. Hasil yang diperoleh bahwa siswa dapat menggunakan E-Training dengan baik. Hal tersebut terlihat dari hasil penilaian angket yang berada pada range 4 dan 5 skala Likert. Proses pelatihan secara online yang dilakukan dapat dilalui sesuai target sehingga lebih efisien terhadap penggunaan waktu dan biaya pelatihan secara offline (Alhooti \& Anto, 2020; Kamal et al., 2016). Selanjutnya jika dilihat dari indikator kemudahan penggunaan aplikasi E-Training, maka perolehan nilai terlihat seperti Gambar 7.

\section{Sebaran Indikator Kemudahan}

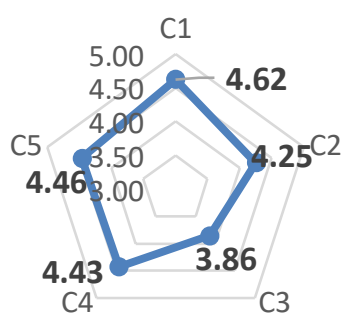

Gambar 7 Sebaran terhadap Indikator Kemudahan 
Gambar 7 menjelaskan bahwa penggunaan aplikasi E-Training tergolong mudah, karena aplikasi E-Training ini bersifat user friendly sehingga siswa dengan mudah menggunakannya. Penilaian yang diberikan siswa terhadap aplikasi E-Training untuk indikator kemudahan berada diatas 3 dengan skala Likert. Aplikasi E-Training yang digunakan karyawan untuk melakukan perencanaan, pengorganisasian, pemantauan, dan evaluasi dilakukan dengan mudah sehingga berpengaruh terhadap kinerja karyawan (Alkali \& Mansor, 2020; Hila et al., 2017). Sementara untuk alokasi waktu yang disediakan pada aplikasi E-Training terlihat seperti Gambar 8.

\section{Sebaran Indikator Alokasi Waktu}

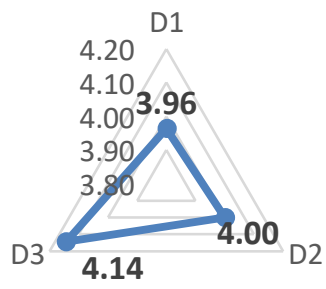

\section{Gambar 8 Sebaran terhadap Indikator Alokasi Waktu}

Gambar 8 memperlihatkan alokasi waktu yang disediakan aplikasi ETraining sesuai dengan kebutuhan siswa dalam mempersiapkan diri untuk menghadapi ujian masuk perguruan tinggi. Hal tersebut sesuai dengan perolehan nilai angket terhadap alokasi waktu berada pada range 4 dan 5. Aplikasi ETraining sangat efektif digunakan untuk melatih kinerja karyawan di masa pandemi COVID-19 jika ditinjau dari sisi waktu (Wolor et al., 2020).

\section{SIMPULAN}

Berdasarkan hasil penelitian yang telah dikemukakan, maka dapat disimpulkan bahwa telah dihasilkan sebuah aplikasi E-Training berbasis Android dalam persiapan ujian masuk perguruan tinggi untuk siswa SMK. Aplikasi ETraining sudah melalui uji validitas oleh pakar dengan kriteria sangat valid dan diujicobakan pada para siswa dan skala kecil dengan kriteria kepraktisan adalah sangat praktis. 


\section{UCAPAN TERIMA KASIH}

Peneliti mengucapkan terima kasih kepada LPPM Universitas Bung Hatta yang telah memberikan biaya penelitian melalui Surat Perjanjian Nomor 093/LPPM-Penelitian/Hatta/IV-2021.

\section{DAFTAR PUSTAKA}

Alhooti, M. J., \& Anto, M. L. (2020). The Effect of E-Training on Employee Performance of Gulf Petrochemical Industries Company in the Kingdom of Bahrain. iKSP Journal of Innovative Writings, 1(1), 42-52.

Alkali, A. U., \& Mansor, N. N. A. (2020). E-Training Integration in Organisation: Modeling Factors Predicting Employee's Acceptance in a Developing Country. European Journal of Molecular \& Clinical Medicine, 7(3), 775798.

Annas, R. I., Purwoko, B., \& Muis, T. (2021). Pengembangan Aplikasi Android Bantuan Diri (Self Help) dalam Perencanaan Pendidikan Lanjutan Siswa Kelas IX MTs Negeri 8 Banyuwangi. Indonesian Journal of Educational Counseling, 5(2), 42-48.

Arpan, M., \& Sadikin, S. (2020). Media Pembelajaran Interaktif Perangkat Keras Komputer. INVOTEK: Jurnal Inovasi Vokasional Dan Teknologi, 20(2), 43-50. https://doi.org/https://doi.org/10.24036/invotek. v20i2.741.

Badan Pusat Statistik. (2021). Tingkat Pengangguran Terbuka (TPT) dalam https://www.bps.go.id/pressrelease/2021/05/05/1815/februari-2021-tingkat-pengangguran-terbuka--tpt--sebesar-6-26-persen.html. Diakses 5 Juli 2021.

Dhir, V., Udawat, P., Shah, R., \& Alahari, A. (2021). Feasibility of an EUS ETraining Course with Live Cases. Endosc Int, 9(8), E1291-E1296. https://doi.org/10.1055/a-1482-8303.

Essays, U. K. (2015). How to Color Affects Mood and Emotion Film Studies Essay dalam https://www.ukessays.com. Diakses 25 Agustus 2021. 
Harris, R., Guthrie, H., Hobart, B., \& Lundberg, D. (2020). Competency-Based Education and Training: Between a Rock and Whirlpool. South Melbourne: Macmillan Publisher.

Hassan, A., Hassan, J., \& Yen, T. A. (2020). E-Training and development, Motivation and Employee Performance among Academicians: Case Study of Academicians in UniMAP. Journal of Physics: Conference Series, 1529(2020), 1-8. http://dx.doi.org/10.1088/1742-6596/1529/3/032011.

Hila, A. A. A., Alhelou, E. M. S., Shobaki, M. J. A., \& Naser, S. S. A. (2017). The Impact of Applying the Dimensions of IT Governance in Improving ETraining - Case Study of the Ministry of Telecommunications and Information Technology in Gaza Governorates. International Journal of Engineering and Information Systems (IJEAIS), 1(8): 194-219.

Instruksi Presiden Republik Indonesia. (2016). Revitalisasi Sekolah Menengah Kejuruan dalam Rangka Peningkatan Kualitas dan Daya Saing Sumber Daya Manusia Indonesia dalam file:///C:/Users/KHAIRU 1/AppData/Local/Temp/Salinan\%20Inpres \%20Nomer\%209\%20Tahun\%202016.pdf. Diakses 9 Februari 2021.

Jumrawarsi, J., \& Suhaili, N. (2020). Peran Seorang Guru dalam Menciptakan Lingkungan Belajar yang Kondusif. Ensiklopedia Educ. Rev, 2(3), 50-54.

Kamal, K. B., Aghbari, M. A., \& Atteia, M. (2016). E-Training \& employees' Performance a Practical Study on the Ministry of Education in the Kingdom of Bahrain. Journal of Resources Development and Management, 18(2016), $1-8$.

Lesmana, S., Muslih, M., \& Saepudin, S. (2021). E-Training Modeling Sistem pada Balai Latihan Kerja Menggunakan Metode Zachman Framework. Jurnal Sains Komputer \& Informatika (J-SAKTI), 5(2), 768-780.

Panyahuti, P., Ganefri, G., Ambiyar, A., \& Suryani, K. (2019). Safe Exam Browser untuk Client Android pada Ujian Berbasis Web. Edukasi: Jurnal Pendidikan, 17(2), 212-226.

Peraturan Pemerintah RI Nomor 32 Tahun 2013 tentang Standar Nasional Pendidikan dalam https://lldikti12.ristekdikti.go.id/2013/06/28/ 
permendikbud-tentang-standar-nasional-pendidikan-juklak-pp-32-tahun2013.html. Diakses 10 Maret 2021.

Puniyanti, N., \& Rahayu, P. (2021). Validitas Media Pembelajaran Video Animasi Matematika Berbasis Pendekatan Kontekstual pada Materi Bangun Ruang Limas. Prosiding Seminar Nasional Penelitian dan Pengabdian Masayarakat.

Purwanto. (2016). Evaluasi Hasil Belajar. Yogyakarta: Pustaka Pelajar.

Putri, A., Azzahra, A., Andiany, D. D., Abdurohman, D., Sinaga, P. P., \& Yuhan, R. J. (2021). Perbandingan Faktor-Faktor yang Memengaruhi Tingkat Pengangguran Terbuka di Indonesia Sebelum dan Saat Pandemi Covid-19. Jurnal Kajian Ekonomi dan Pembangunan, 3(2), 25-46.

Schulte, S., Richter, T., \& Grantz, T. 2014. Digital Media as Support for Technical Vocational Training: Expectations and Research Results of the Use of Web2. 0. International Journal of Advanced Corporate Learning (iJAC), 7(3), 29-32.

Sila, V. U. R., \& Kamaludin. (2021). Persepsi Mahasiswa Universitas Timor Prodi Pendidikan Biologi terhadap E-Learning pada Kondisi Pandemi Covid-19. Jurnal Pendidikan, Matematika dan Sains, 5(2), 123-138. https://doi.org/10.33541/edumatsains.v5i2.2191

Syahmaidi, E. (2017). Design Module Training in Micro Vocational Education. International Journal of Research in Engineering and Social Sciences, 7(2), 7-14.

Vann, D. M., Riggs, D. W., \& Green, H. J. (2021), Implementing a Brief E-Training Opportunity for Mental Health Practitioners Working With Non-Binary Clients. Australian Psychologist, 56(4), 299-310. https://doi.org/10.1080/00050067.2021.1921556.

Wolor, C. W., Solikhah., Fidhyallah, N. F., \& Lestari, D. P. (2020). Effectiveness of E-Training, E-Leadership, and Work Life Balance on Employee Performance during COVID-19. Journal of Asian Finance, Economics and Business, 7(10), 443-450. 